\title{
Teacher roles in designing technology-rich learning activities for early literacy: A cross case analysis
}

Citation for published version (APA):

Cviko, A., McKenney, S., \& Voogt, J. (2014). Teacher roles in designing technology-rich learning activities for early literacy: A cross case analysis. Computers \& Education, 72, 68-79.

https://doi.org/10.1016/j.compedu.2013.10.014

DOI:

10.1016/j.compedu.2013.10.014

Document status and date:

Published: 01/03/2014

Document Version:

Early version, also known as pre-print

Document license:

CC BY-SA

Please check the document version of this publication:

- A submitted manuscript is the version of the article upon submission and before peer-review. There can be important differences between the submitted version and the official published version of record. People interested in the research are advised to contact the author for the final version of the publication, or visit the DOI to the publisher's website.

- The final author version and the galley proof are versions of the publication after peer review.

- The final published version features the final layout of the paper including the volume, issue and page numbers.

Link to publication

\section{General rights}

Copyright and moral rights for the publications made accessible in the public portal are retained by the authors and/or other copyright owners and it is a condition of accessing publications that users recognise and abide by the legal requirements associated with these rights.

- Users may download and print one copy of any publication from the public portal for the purpose of private study or research.

- You may not further distribute the material or use it for any profit-making activity or commercial gain

- You may freely distribute the URL identifying the publication in the public portal.

If the publication is distributed under the terms of Article 25fa of the Dutch Copyright Act, indicated by the "Taverne" license above, please follow below link for the End User Agreement:

https://www.ou.nl/taverne-agreement

Take down policy

If you believe that this document breaches copyright please contact us at:

pure-support@ou.nl

providing details and we will investigate your claim.

Downloaded from https://research.ou.nl/ on date: 26 Apr. 2023 
PrePrint of: Cviko, A., McKenney, S. \& Voogt, J. (2014). Teacher roles in designing technology-rich learning activities for early literacy. Computers \& Education, 72, 68-79.

Teacher roles in designing technology-rich learning activities for early literacy: A cross-case analysis

\title{
Keywords
}

Teacher role; Technology-integration; Early literacy

\begin{abstract}
The present study aims to provide insight into the value of different teacher roles in designing and implementing technology-rich learning activities for early literacy. Three cases, each with a different teacher role (executoronly, re-designer, co-designer) were examined. In the executor-only role, teachers implemented ready-made activities. In the re-designer role teachers collaboratively re-designed existing activities, and in the co-designer role, teachers collaboratively designed new activities. In each role, teachers implemented the learning activities. Ten teachers and ten classes participated in the three cases. Teacher perspectives about their assigned role, the practicality of the technology-rich learning activities, and co-ownership were measured using interviews. Technology integration was observed during curriculum implementation. Pupil early literacy learning outcomes were measured using a pre-test post-test quasi experimental design. Positive perspectives about the assigned role, curriculum practicality and a sense of co-ownership were found in the co-designer case. Concerns about practicality of technology-activities were raised in the executor-only and re-designer cases. Teachers in the redesigner case were reserved about the role assigned to them. The extent of integration of technology-rich activities was highest in the co-designer case and lowest in the executor-only case. Significant learning gains were found for each teacher role. This study concludes that involving teachers in design of technology-rich activities positively affected teacher's perceptions and implementation, and that each teacher role (executor-only, re-designer, co-designer) contributed to the effectiveness of technology-rich activities.
\end{abstract}

\section{Introduction}

The teacher's role in creating and facilitating children's learning in technology-rich classrooms is increasingly becoming important in supporting early literacy development. Even though teachers expect rapid increases in the use of technology-rich learning materials, this is not yet seen in practice (ten Brummelhuis \& van Amerongon, 2010). In an effort to improve language education in Dutch primary schools, national attainment targets as well as interim goals for early literacy have been formulated to help kindergarten teachers focus their efforts (Tomeson, van Koeven, Schippers, \& Klein Tank, 2008). While research has shown that technology can offer valuable tools for developing early literacy (e.g. Cheung \& Slavin, 2012), kindergarten teachers are still struggling to integrate them effectively (cf. Bølgan, 2012). Integrating technology refers to the process in which technology is used as a tool to support teaching and pupil learning (Keengwe \& Onchwari, 2009). How teachers integrate technology-rich learning activities is presumed to affect pupil learning outcomes (Levy, 2009). A teacher's meaningful integration of computer-supported activities can enhance pupil early literacy development (Hyun \& Davis, 2005). Benefits for young children in terms of enhanced learning outcomes indicate effectiveness of technology-rich activities for early literacy (e.g. Tracey \& Young, 2007). In this study, effectiveness of ICT-rich activities is defined in terms of pupil early literacy learning outcomes. 
Research in the field of early literacy has established links between: (a) teacher involvement in designing pupil learning activities (Perry, Hutchinson \& Thauberger, 2007); (b) implementation of literacy curricula (Dickinson \& Caswell, 2007; Neuman \& Cunningham, 2009); and (c) pupil learning outcomes (McCutchen, Abbot, Green, Beretvas,

Cox, Potter, Quiroga, \& Gray, 2002). However, few studies explore the role of teacher involvement in developing learning activities, implementing them, and commensurate pupil learning outcomes.

Teachers' perspectives about teaching/learning, technology, and subject matter influence classroom implementation (Tondeur, Hermans, van Braak, \& Valcke, 2008). Further, the implementation of technology-rich curricula can be influenced through interrelated factors, including teacher perceptions about their role during implementation (Broadhead, 2001); notions about curriculum practicality (Doyle \& Ponder, 1978) and co-ownership of the curriculum (Fullan, 2011). The manner in which teachers are involved in the design and implementation of technology-rich learning activities could influence how they perceive their role, practicality and co-ownership, and thereby actual implementation and pupil learning outcomes.

The present study is based on the assumption that teacher involvement in curriculum design influences curriculum implementation and thereby pupil learning outcomes. By investigating three different roles for teachers (executor-only re-designer, co-designer) this study seeks to explore their contribution to implementation and pupil early learning outcomes. The study involves kindergarten teachers in the development and implementation of specific technology-rich learning activities and materials, called PictoPal. Based on a subset of Dutch national interim goals for early literacy, PictoPal features integrated on- and off-computer activities, which can be used in multiple ways. Teachers can (collaboratively) create their own content (co-design), modify existing content (re-design), or simply implement what is already provided (executor-only). This study seeks to understand which of these three teacher roles contributes most to developing early literacy in pupils. Specifically, differences and similarities pertaining to the aforementioned interrelated sets of factors: teacher perspectives about teaching/learning, early literacy, technology, teacher perceptions about their assigned role, practicality of curriculum and co-ownership; curriculum implementation; and pupil learning outcomes are examined across teachers who were involved with PictoPal in different ways (as co-designers, re-designers, or only executors).

\section{Theoretical framework}

\subsection{Roles of teachers in curriculum design}

A teacher's primary task is to engage pupils in activities that enhance their learning outcomes (Keengwe \& Onchwari, 2009). To implement technology successfully, teachers need to understand why technology tools are important to young children, how to use teaching strategies, and apply the technology tools in the classroom (Parette, Quesenberry, \& Blum, 2009). According to Hutinger, Bell, Daytner, and Johanson (2006) teachers need help in developing an understanding of how implementation of technology integration will impact 
children, and time to make the change. Active involvement in the design of technology integrated activities can help teachers implement them effectively in their classrooms.

Teacher engagement in curriculum design could influence teacher perceptions about their role in curriculum implementation, their sense of co-ownership and curriculum practicality (cf. Fishman, Marx, Best, \& Tal, 2003). Teachers can have different roles in curriculum design: executing ready-made plans only, re-designing existing learning activities and materials, or (collaboratively) designing new ones (Carl, 2009; O’Donnell, 2008; Roschelle, Penuel, \& Schechtman, 2006). Higher role acceptance may be expected among the redesigners than the co-designers, because re-design is a natural activity for most teachers, whereas co-design may require more effort than teachers are used to. Similarly, executors, redesigners and co-designers may differ in their expectation of the benefit of implementation for their pupils. According to McGrail (2005) teachers are likely to accept technological change when they are convinced of benefits for their pupils and teaching. According to Abrami, Poulsen, and Chambers (2004), teacher perceptions about costs and successful implementation and value of an innovation explain about $43 \%$ of the variance in curriculum use. Teachers participation in team design (as re-designers or co-designers) can yield a greater sense of co-ownership toward the resulting products (Kirk \& MacDonald, 2001), than when not involved in design. Further, benefits for ownership are likely to be higher in the codesigner role than in the re-designer role, since the freedom and amount of teacher input is greater in the co-designer role. Taken together, teacher roles in design (re-designer and codesigner) may enhance teacher perceptions of practicality of newly designed technology richactivities, contribute to how teachers integrate technology, and influence overall effectiveness (i.e. pupil learning). Based on the assumption that the roles in design may be more effective than no participation in design, the focus of this study is to investigate which teacher role (executor-only, re-designer, co-designer) yields the greatest effect on technology integration and pupil learning outcomes.

\subsubsection{Teacher role 'executor'}

Teachers often take on the role of executing existing curricula (Carl, 2009). In this role, teachers receive a ready-made curriculum, and can be assumed to have had minimal involvement in the curriculum design. For primary school teachers, executing a new curriculum typically involves anticipating changes/implications for one's teaching role, and coping with concerns about materials and resources required to support implementation (Broadhead, 2001). During implementation, teachers in this role adapt the curriculum to their classrooms settings, for instance to pupil needs and their own pedagogical values (Squire, MaKinster, Barnett, Luehmann, \& Barab, 2003).

\subsubsection{Teacher role 're-designer'}

In the re-designer role, teachers actively take part in the development process by contributing to changes not only during use (e.g. reshaping activities), but also in re-designing the actual resources. This is often done together with other teachers. Not only is this a practical process through which teachers fine-tune things for their own purposes, but it can also be beneficial for teachers to engage in analyzing curriculum together with colleagues, e.g. to deepen their own understanding of the subject matter (Grossman \& Thompson, 2004). 
The active involvement of teachers in re-designing curriculum also stands to contribute to its implementation. Other benefits could be co-ownership, since teachers as re-designers have a clear voice in curriculum development (Carl, 2009). Taking the role of re-designer requires teachers to invest time and effort in (collaborative) work to re-design existing activities and execute the re-designed curriculum.

\subsubsection{Teacher role 'co-designer'}

Co-designers take part in the development process by participating actively in creating new resources, often together with other teachers (Penuel, Roschelle, \& Schechtman, 2007). Extending existing resources with self-made learning materials can be motivational to teachers (Herrington, Specht, Brickell, \& Harper, 2009) and create a sense of co-ownership towards the materials. Co-design stimulates actual use, since teachers engage in developing resources that fit into their classroom contexts (Penuel et al., 2007). Like the re-designer, the co-designer also works to create and implement curriculum activities, but those of the codesigners are new (as opposed to revised).

\subsection{Factors influencing curriculum implementation and pupil attainment}

The following section describes the factors found in prior research to be relevant for curriculum implementation and pupil attainment. Also, curriculum implementation and pupil learning outcomes are discussed as potential indicators of effectiveness of technology-rich curriculum activities.

\subsubsection{Teacher perspectives about teaching/learning, technology and early literacy}

Teacher perspectives about teaching/learning, technology, and subject matter are related to the way teachers implement technology-rich curricula (Tondeur et al., 2008). In K-8 settings, Kim, Kim, Lee, Spector, and DeMeester (2013) found that teacher perspectives about effective ways of teaching are reflected in their technology integration practices. Teacher perspectives about technology's impact on teaching/learning are found to influence technology integration (Inan \& Lowther, 2010).

\subsubsection{Teacher perspectives about their role in design}

According to Handler (2010), teacher roles in curriculum design and implementation has become central to effective realization of educational innovations. What teachers think about the roles to which they are assigned in curriculum innovation seems important for successful implementation. Broadhead (2001) found that teachers perceive a shift in their role with regard to the implementation of a new curriculum, for instance expecting to be less directive to pupils.

\subsubsection{Teacher perspectives about curriculum co-ownership}

Teachers' sense of ownership towards a new curriculum is suggested to positively influence curriculum implementation (Fullan \& Watson, 2000). Roschelle et al., (2006) found that primary school teachers' sense of ownership evolved over the course of a school year. When teachers were initially involved in the co-design and use of technology in the classroom, they reported feeling that technology was at least partly theirs; while by the end, the teachers became strong advocates of technology use. Teacher ownership towards a new curriculum seems to depend on how teachers are involved (Kirk \& MacDonald, 2001). Also, 
to create sustainable technological interventions, teachers require time to develop ownership (Ketelhut \& Schifter, 2011).

\subsubsection{Teacher perspectives about curriculum practicality}

Considerations about the practicality of an innovation can affect how teachers implement technology. According to the classic work of Doyle and Ponder (1978), teachers judge curriculum practicality on three elements: instrumentality (how well a curriculum is specified); congruence (how well a curriculum fits their own beliefs, including beliefs about pupil needs); and cost (the ratio of efforts required to potential benefits gained). Similarly, a recent study by Shirley, Irving, Sanalan, Pape, and Owens (2011) demonstrated that teachers implementing a technology innovation consider: the alignment of the innovation with their beliefs, as well as the benefits of the innovation compared to accompanying challenges. When a curriculum is well-specified (e.g. including well-structured teacher guides with clear learning objectives and classroom activities), it can be easier for teachers to implement and pupil benefits can increase (Assel, Landry, Swank, \& Gunnewig, 2006). How teachers perceive technology applications to align with their current curriculum is found to be positively related with their perceptions concerning usefulness, learning opportunities, possibilities for successful use, and intention to use technology (De Grove, Bourgonjon, \& Van Looy, 2012). When teachers perceive a curriculum as useful, they seem likely to implement it, despite potential costs (cf. Broadhead, 2001; Wozney, Venkatesh, \& Abrami, 2006).

\subsubsection{Curriculum implementation}

According to O'Donnell (2008), measures of implementation can help explain if unsuccessful outcomes are due to an ineffective program or due to a failure to implement the program as intended by its designers. In a meta-analysis concerning studies examining K-12 pupils' reading outcomes and technology-based curricula, studies with medium or high implementation ratings were associated with positive effects on pupil learning; while studies with low implementation ratings were associated with no effect (Cheung \& Slavin, 2012). The authors suggested cautiousness when interpreting the findings, since studies with no effects would be likely to describe low extent of implementation as a reason for no experimental-control differences. Frechtling, Zhang, and Silverstein (2006) found that implementing essential features of a program - for instance provision of extra support to struggling pupils, and consistent use of the curriculum guides - made a significant difference in student learning. In implementing PictoPal (the tool used in this study), Verseput (2008) found that more than on-computer activities only, the integration of on-and off-computer activities supported early literacy learning of pupils. Central to the implementation of technology-rich learning activities, is integration into curricular activities in a functionally significant manner (Amante, 2007; McKenney \&Voogt, 2009).

\subsubsection{Pupil early literacy learning outcomes}

The attained curriculum, that is pupil learning outcomes, is often used as a measure of curriculum effectiveness (Fishman et al., 2003). Pupil learning outcomes have also been used as a measure of professional development effectiveness. For example, Lowther, Inan, Ross, and Strahl (2012) found no significant differences in achievement between pupils whose 
teachers were and were not involved in a technology use and implementation program. Yet others (e.g. Block, Campbell, Ninon, Williams, \& Helgert, 2007) found that experimental subjects outperformed controls in early literacy outcomes following a full day of sessions concerning how to use the technology in the classroom.

\section{Research questions}

With the understanding that teacher perspectives and curriculum implementation influence pupil learning outcomes, the study sought to explore the comparative benefits and drawbacks of each role in terms of contributions to pupil learning outcomes. The present study provided teachers with different roles in curriculum design and implementation: executor-only, redesigner and co-designer. Across the teacher roles, the data were collected to examine differences and similarities in teacher perspectives (about their own role; practicality of the activities; and co-ownership of the designed curriculum activities); integration of the designed activities with classroom work during implementation; and pupil learning outcomes. During implementation, data collection focused on the integration of technology-rich learning activities with off-computer activities. The effectiveness of technology-rich learning activities and materials was measured through pupil learning outcomes. The research question guiding this study was: "What role (executor-only, re-designer and co-designer) for primary school teachers, contributes most to the effectiveness of technology-rich learning activities for early literacy and why?" The sub-questions were:

$R Q 1$ : Is there a difference between perspectives of teachers in the roles of executor-only, re-designer, and co-designer respectively on teacher perceptions of: own role, curriculum practicality, and curriculum co-ownership?

RQ2: Is there a difference in the integration of technology-rich activities in an early literacy curriculum by teachers in the roles of executor-only, re-designer, and co-designer respectively?

RQ3: Is there a difference between pupil learning outcomes when teachers adopt the roles of executor-only, re-designer, and co-designer respectively?

\section{Method}

\subsection{Study design}

Because school year-long, in-depth investigation into each teacher role (including several teacher and pupil related measures) was needed, a multiple case-study design (cf. Yin, 2003) was determined the most suitable approach for examining each role. Each type of teacher role was a separate case. The cases, which were considered the units of analysis in the study, were compared on a same set of variables using a cross-case analysis (Miles \& Huberman, 1994). Specifically, the variables were: (1) teacher perspectives about: their roles, curriculum practicality, and co-ownership; (2) technology integration; and (3) pupil early literacy outcomes. 


\subsection{Context: PictoPal}

Engaging in the meaningful creation of texts and consecutively using the written products supports young children in developing an understanding of written language (McKenney \& Voogt, 2009). PictoPal is based on a subset of the Dutch national interim goals for early literacy and aims to foster pupil understanding of: (1) the functions of written language; (2) functional reading and writing; (3) the relationship between spoken and written language; and (4) linguistic awareness. The PictoPal format consists of eight on-computer activities and eight off-computer activities. On-computer activities are created in the software program, Clicker ${ }^{\circledR}$. This enables pupils to 'read' words with help of pictograms and voice output, and 'write' depicted words by clicking on them. Once written, children can have the computer read back to them individual words, single sentences, or an entire document. Through this process, pupils create meaningful texts together with their peers, which are then used in offcomputer activities. For example, recipes are 'cooked', books are 'read', and weather forecasts are 'broadcasted' by pupils in the classroom. Shown in Figure 1, children compose their stories about spring (on-computer) and later read aloud to the class (off-computer). Previous research has demonstrated that PictoPal use can yield statistically significant pupil learning gains (McKenney \& Voogt, 2009), and that these appear to be influenced by how teachers integrate the on-computer activities with other, off-computer language activities (Verseput, 2008).

-Insert Fig. 1 about here-

The term, PictoPal, pertains to the unique combination of on-computer and off-computer activities which is structured in a particular way. While the specific vocabulary and contents of each PictoPal modules varies, the structure is its defining feature, and this remains static. Consistent structural elements of PictoPal are: (1) brief preparatory activities before writing commences (usually small-group discussion concerning focusing on the content of the writing task); (2) the number of integrated on-computer- and off computer activities (eight in each module); (3) gradual increase in difficulty level (e.g. starting with single-sentences and ending with complete paragraphs); (4) same range of text types used (e.g. list, letter, story); (5) same (graphic) vocabulary within text types; (6) same conventions in screen layout; (7) each module relates to a broad unifying theme; (8) each off-computer activity entails the use of the written text for its given purpose (e.g. a grocery list is used in the shopping store corner of the classroom); and (9) a teacher guide offering support for the preparatory activity, the oncomputer activity and the off-computer activity.

Across cases, the static structural elements of each PictoPal module remained consistent. To safeguard consistency, one technology supporter rendered all the PictoPal content in Clicker ${ }^{\circledR}$ for each case. Executors were given a ready-made module: Spring. Re-designers adapted Spring to Winter, and co-designers created a set of activities with the theme: Nature. The latter two collaboratively created paper prototypes of the activity descriptions and oncomputer materials. While vocabulary and specific content differed across modules, each adhered to the structural elements described above. 


\subsection{Participants}

The study of teacher roles in the design of PictoPal was carried out over three years, involving kindergarten teachers in PictoPal execution-only (Cviko, McKenney, \& Voogt, 2012), re-design (Cviko, McKenney, \& Voogt, 2013) and co- design. In each study, a particular teacher role was assigned to teachers. A sub-set of participants in previous studies was used for this cross-case investigation. In total, ten teachers from four schools teaching ten kindergarten classes participated in this study. In the role of 'executor-only', the Spring module was implemented by four teachers in 2009. In the role of 're-designer', Spring was redesigned into Winter and implemented by three teachers in 2010. In the role of 'co-designer', Nature was co-designed and implemented by three teachers in 2011. Table 1 shows an overview of the participating teachers per case, their teaching experiences, the schools and the classes (junior versus senior kindergarten) they were teaching.

-Insert Table 1 about here-

Table 2 shows an overview of the number of pupils per teacher role, gender and age. There was an age difference between junior pupils in the executor-only and re-designer cases, $t(113)=4.650, p=.00$, with higher mean for junior pupils in the executor-only case than in the re-designer case. The mean difference for junior pupils was three months. No age differences were found between senior pupils in the executor-only case and senior pupils in co-designer case $t(58)=0.536, p=.59$.

For the executors and re-designers, the control group consisted of pupils from the same school (1) as the experimental group pupils. The control group for the co-designer case also came from school 1, because adding a control group for this case from the same school was not feasible. The experimental and control groups were comparable on basis of the similar approach to teaching kindergarteners in their schools. The teachers in the three cases had similar perspectives on teaching and learning, early literacy teaching, and learning and computer use in kindergarten as established during a pre-intervention interview.

-Insert Table 2 about here-

\subsection{Instruments}

\subsubsection{Interview}

A semi-structured interview was used to study teacher perspectives about their role, curriculum practicality, and co-ownership. An interview scheme guided the interviews with the teachers in each case. An example question is: "What are your views on your role as a redesigner of PictoPal?" 


\subsubsection{Observation checklist}

To study the implementation of PictoPal, an existing integration checklist (Verseput, 2008) was used to measure the extent of integration of PictoPal on- and off-computer activities. Representing features of good early literacy teaching regarding integration of technology-related activities in classroom practice, the integration checklist contains 12 items measuring the extent of teachers' integration of on- and off-computer activities: (1) Involving pupils; (2) Initiating listening; (3) Initiating speaking; (4) Initiating writing; (5) Initiating reading; (6) Play with writings; (7) Initiating activity; (8) Initiating collaboration; (9) Initiating individual work; (10) Providing support; (11) Initiating talk on process; and (12) Initiating talk on products. The items were scored on a three-point scale $(0=$ absent; $0.5=$ observable to some extent; 1 = observable to a great extent). An example of item 12 is: "The teacher encourages pupils to talk about their created products". In each case, two researchers observed two activities and discussed their scorings. Since the research assistants were not consistent across the three case-studies, the inter-rater reliability was calculated for each study and considered acceptable. The inter-rater reliability for executor-only case was found to be Cohen's kappa $=.67(p<.001)$; for re-designer case Cohens' kappa $=.71,(p<0.001)$, and for co-designer case Cohen's kappa $=.63,(p<0.001)$, indicating sufficient agreement.

\subsubsection{Early literacy test}

To study pupil early literacy outcomes, a test for early literacy for 4-5 year olds was used (McKenney \& Voogt, 2006). The test consists of items measuring early literacy skills regarding the purposes of reading and writing, linking spoken and written language, functions of written language, and language awareness. The test was designed to ascertain if and how well those learning goals, which are part of the Dutch national interim goals for early literacy, are being achieved. An overview of the test featuring one sample item for each (sub-) goal is provided in Appendix 1. In each case-study, the same test with 17 items was used. However, because of a ceiling effect found in the executor case-study (2009), three new items were added to the test to expand its difficulty level. In the executor-only case-study (2009), three of the items were not included in the analysis, because these decreased the reliability of the test. In the executor case-study, a ceiling effect seemed to have impaired the measurement of senior pupils early literacy. For this reason, a 20 item version of the same test was used in the re-designer case-study (2010) and the co-designer case-study (2011).

The items were scored on a two-point scale $(0=$ not correct; $1=$ correct $)$. An example item is the following task: (1) The researcher sets out color pencils, a pen, paper, scissors, a coloring page, a book, a spoon, a postcard and a grocery list; (2) the researcher presents the items to the child with an open arm gesture and says, "Can you pretend that you are writing something". The item is scored as correct if the child takes either a pencil or a pen and a sheet of paper, and does or imitates the act of writing. For executor-only case ( $N$ of items $=14$ ), Cronbach's alpha was .76 on the pre-test and .87 post-test data. For re-designer case ( $N$ of items $=20)$, Cronbach's alpha was .71 on the pre-test and .71 for the post-test data. For codesigner case ( $N$ of items $=20$ ), Cronbach's alpha was .64 on the pre-test data and .68 for the post-test data. Cronbach's alpha coefficients between .60 and .70 and above are suggested to imply reliability at an acceptable level (DeVellis, 1991). 


\subsection{Procedure}

The data on teacher perspectives about their roles, curriculum practicality and coownership were gathered after PictoPal-implementation. About their roles, teachers were interviewed individually in all three cases. About curriculum practicality, executor-only teachers were interviewed in a group interview, while re-designer and co-designer case teachers were interviewed individually. Re-designer and co-designer teachers were also interviewed individually about their co-ownership toward PictoPal (co-ownership was not relevant for executor-only case).

In each case, the duration of PictoPal implementation was eight weeks. Implementation data were gathered for all eight activities per teacher, except for re-design teacher Jet, who did not implement the first and eighth activity, due to time constraints. In each case study, pupils in the experimental and control groups were tested on early literacy prior to and after PictoPal-implementation.

Participants were assigned to one of the cases (executor-only; re-designer; or co-designer) using three criteria:

(1) Experience: The teacher has no previous experience with (re-)designing or implementing PictoPal;

(2) Timing: Teachers implement PictoPal in the same period of the school year.

(3) Activity types: Executor-only teachers implement ready-made PictoPal activities, redesigner teachers implement their re-designed PictoPal activities, co-designer teachers implement their co-designed PictoPal activities.

Within each case study, data on the variables (teacher perspectives, implementation and pupil learning) were used for the cross-case analysis.

\subsection{Data analysis}

To prepare the cross-case analysis, a data matrix was used to display (per case) teacher perspectives about their roles, curriculum practicality and co-ownership. Data from interviews was entered in a table with teacher perspectives in columns and cases in rows. Then, teacher perspectives data of were summarized per case to allow for scanning across the three cases for commonalities and differences per variable (Miles \& Huberman, 1994).

The data on implementation were analyzed using analysis of variance. For interpreting effect sizes for $\eta 2$, Cohen's (1988) rule of thumb was used defining effects: .01 indicates a small effect, (about $1 \%$ of the total variance accounted for by group membership); .06 indicates a medium effect; and .14 indicates a large effect. Pupil learning data were analyzed using analysis a of covariance, with pupil pre-test learning outcomes as a covariate. Afterward, relationships between variables were studied by relating variable outcomes in each case. 


\section{Results}

\subsection{Perspectives of teachers on role, practicality, and co-ownership across cases}

The perspectives of teachers about their roles, curriculum practicality and co-ownership were compared across the three cases (executor-only, re-designer and co-designer). Table 3 summarizes the findings of the cross-case analysis of teacher perspectives.

-Insert Table 3 about here-

\subsubsection{Teacher role perspectives}

As shown in Table 3, the cases differed with regard to teacher perspectives about their roles. Executors welcomed their role. For example, Carol liked 'being provided with materials', and Alice felt 'at ease executing PictoPal'. When asked about only executing, Fiona and Alice seemed to adjust curriculum activities during implementation. Fiona reported 'there is always something missing or too much represented'. According to Alice '...you are adjusting it too, you are not doing exactly what is prescribed'.

According to re-designer teachers, this role was not the teachers' job. For example, Mira felt the role was: 'not fitting the task and the responsibility of a teacher'. She explained that: 'sometimes adaptation during implementation might be even more valuable than a role of redesigner, for example when children do not enjoy an activity, a teacher can adapt it'. Also, teacher Jet felt the re-designer role was not the teachers role: 'the role makes a teacher reflect about own actions and think about classroom organization, yet it is not a regular practice'.

Co-designers embraced their role. When asked about this role, Carla explained 'feeling codesigner...having gained understanding of what PictoPal is all about'; Maria felt 'intensively involved in designing' and Jenny said she was 'activating and quickly responding, focused on finalizing co-design'.

\subsubsection{Curriculum practicality perspectives}

Table 3 shows differences between cases with regard to perspectives about PictoPal practicality. Executor-only and re-designer teachers were somewhat concerned about the congruency between PictoPal and pupil levels. Executor-only teachers appeared to perceive PictoPal as difficult for junior pupils. They expressed the need for re-designing PictoPalactivities to suit better the level of junior pupils.

Re-designer teachers wanted pupils to use PictoPal independently. According to Jet, the 're-designed activities were appealing and aligned to pupils' world views, ...re-design was necessary so that junior and senior pupils could work on their own levels.' However, redesigner teachers seemed to be concerned about junior pupil abilities to work independently, without teacher guidance. For example, Iris felt 'working with PictoPal was difficult, ...when reading their writings, junior kindergarteners searched for words, which is easier for senior kindergarteners'. Mira explained: 'teachers must help children with written products.' Redesigner teachers were positive about the ratio of effort invested in re-design and the benefits gained. 
Co-designer teachers were positive about practicality of PictoPal, and they wanted to continue working with it. According to Maria, the co-designed 'PictoPal is congruent with pupils' needs'. Co-designer teachers were positive about the ratio of effort invested in codesign and the benefits gained. Carla experienced implementation as a reward for the codesign effort, while viewing PictoPal beneficial for pupil learning'.

\subsubsection{Co-ownership perspective}

Only re-designer and co-designer teachers were asked about co-ownership. As shown in Table 3, re-designer teachers felt more like contributors. Jet reported that she had 'only contributed ideas to the product'. Also, Iris felt she 'contributed to [re]-designing the product, but did not feel like a designer of the product'. Mira explained her position of contributor in respect to that of the original designers: 'I assume that it eventually will be your product, and if we write it [re-design it] I do not think you can still say that it is your product.' However, co-designer teachers reported feeling co-owners of PictoPal. Jenny reported 'feeling fully a co-owner of the co-designed product as they provided a reasonable input themselves in the form and content of PictoPal'. Carla felt somewhat co-owner, since 'she did the design together with other team members', and Maria felt 'commitment, as ownership would be a bit overrated' (owing to the result being a team product).

\subsection{Curriculum implementation across cases}

Varieties in integration were examined across teacher roles. All teachers in the executoronly and co-designer cases implemented the on- and off-computer activities during eight weeks. In the re-designer case, the first and the sixth off-computer activity was not implemented by one teacher (Jet) due to time constraints.

\subsubsection{Integration of on-off computer activities across roles}

Table 4 shows the means and standard deviations of the results of the integration checklist per teacher role. Fig. 2 shows a distribution of the mean observation score on the twelve integration items for each teacher role. To test the hypothesis that there was no difference in integration between teachers roles, an ANOVA was performed with the extent of integration as the dependent variable and the case (executor-only, re-designer and co-designer) as independent variable. This showed a difference for teacher case $F(2,77)=12.930, p=0.03$, $\eta^{2}=0.25$. This difference could be interpreted as large (Cohen, 1988), since $25 \%$ of the variance in integration scores can be explained by teacher role. To reveal differences between the roles a post hoc test was performed. This showed that co-designer teachers integrated the on- and off-computer activities to a significantly higher extent than the executor-only teachers $(p=.001)$ and re-designer teachers $(p=.01)$. Further, re-designer teachers integrated the onand off-computer activities to a significantly higher extent than executor-only teachers $(p=$ .04). Finally, the co-designer case had a smaller standard deviation compared to executor-only and re-designer cases, which could indicate that co-designer teachers had a relatively high extent of integration throughout implementation. 
-Insert Fig. 2 about here-

\subsubsection{Implementation over time}

Fig. 3 shows the distribution of the observation data on curriculum implementation over time (results of the integration checklist per week per teacher role). A regression analysis was performed with time (eight weeks in which teachers implemented eight on-and off computer activities) and case (executor-only, re-designer and co-designer) as independent variables and integration as dependent variable. A main effect was found for the duration $\beta=.487, p=.00$, $\eta 2=.39$ and a main effect was found for teacher role $\beta=.499, p=.00, \eta 2=.40$. Duration and teacher role are each significant predictors for integration of on-and off computer activities. The effect sizes can be regarded as large effects according to conversion table suggested by Cohen (1988). There was no significant interaction between time and case. A combination of teacher role and duration is not a significant predictor for the extent of integration.

-Insert Fig. 3 about here-

\subsection{Pupil learning outcomes within and across cases}

Within each case (executor-only, re-designer and co-designer), pupil early literacy outcomes were compared between experimental and control groups. Table 5 shows pupil learning outcomes in the three experimental conditions and the respective control groups. To test the hypothesis that pupil learning outcomes do not differ between the experimental groups and control groups a series of ANCOVA's were performed with pupil post-test scores as dependent variable, group (experimental versus control) as an independent variable and pre-test as a covariate.

In the executor-only case, significant differences between junior pupil learning outcomes were found for group $F(1,70)=17.524, p=.00, \eta 2=.20$. Junior pupils in the experimental group scored higher $M=10.98$ than junior pupils in the control group $M=8.60$. Also, significant difference between senior pupil learning outcomes was found for group $F(1,87)=$ $17.535, p=.00, \eta 2=0.17$. Senior pupils in the experimental group scored higher $M=12.28$ than the senior pupils in the control group $M=10.95$. As mentioned previously, the findings in the executor-only case are based on 14 of the 17 -item test for early literacy. The effects for both senior and junior pupils appears to be large, since about $20 \%$ and $17 \%$ of the variance respectively is accounted for by group. 
In the re-designer case, significant difference between junior pupil learning outcomes was found for group $F(1,87)=11.963, p=.00, \eta 2=0.12$. Junior pupils in the experimental group $M=12.40$ scored higher than junior pupils in the control group $M=10.47$. This finding is based on the 17-item test with 3 additional items (20 in total, as discussed earlier). Also, for junior pupils in re-designer case, the effect size appears to be large, since about $12 \%$ of the variance is accounted for by group.

In the co-designer case, significant differences were found between experimental and control group senior pupil learning outcomes $F(1,102)=4.829, p=.03, \eta 2=0.05$. Senior pupils in the experimental group $M=16.14(S D=2.20)$ scored higher than senior pupils in the control group $M=15.00$ ( $S D=3.05)$. This finding is based on the $17+3$ (20 total)-item test. The effect appears to be small, since about $5 \%$ of the variance is accounted for by group.

The effect sizes (Cohen's $d$ ) for senior pupils in the executor-only case (Cohen's $d=1.09$ ) and co-designer case $(d=1.02)$ indicate that in both groups the intervention had a large effect on pupil learning outcomes. Also, for junior pupils in both the executor-only (Cohen's $d=$ 1.75) and re-designer cases (Cohen's $d=1.41$ ) the effect sizes are large, indicating that the interventions had large effects on pupil learning.

-Insert Table 5 about here-

\section{Discussion}

\subsection{Summary of the findings}

Findings showed differences in teacher perspectives between teacher roles. In contrast to re-designer teachers, executor-only teachers welcomed and co-designer teachers embraced their roles. With regard to curriculum practicality, executor-only and re-designer teachers seemed to view technology-rich activities as less suitable for independent use by (junior) kindergarteners. A sense of co-ownership seemed greater in co-designer teachers, than in redesigner teachers. Implementation findings indicate significant differences between teacher roles. Co-designer teachers integrated activities to a higher extent than re-designer and executor-only teachers. Re-designer teachers integrated activities to a higher extent than executor-only teachers. Significant differences in pupil learning outcomes were found between experimental and control groups for each teacher role. The findings on pupil learning outcomes suggest large effects for both junior pupils with teachers in executor-only and redesigner roles, and for senior pupils with teachers in executor-only and co-designer roles. Pupils from classes of executor-only teachers had high learning outcomes, although the extent of integration of executor-only teachers was significantly lower compared to re- and codesigner teachers. High levels of on- and off-computer integration did not accompany high pupil learning outcomes. 


\subsection{Limitations}

The eight weeks of duration of PictoPal may have limited the study to detect effects in pupil learning outcomes between teacher roles. A longer period of time for implementation could provide more insight in effectiveness of PictoPal, since time for implementation has been found to yield enhanced pupil early literacy learning outcomes (Landry, Swank, Anthony, Assel, 2012; Hutinger, et al., 2006). Also, there may have been some variation in the quality of the three modules. While the effect sizes for pupil learning were higher with the re-designed module (than co-designed) and highest with the researcher-designed module, it is also notable that significant pupil learning gains were found in all cases. Despite the potential ceiling effect previously detected with senior pupils (Cviko, McKenney, \& Voogt, 2012), this study indicated large effects for learning gains of PictoPal for senior pupils groups in classes of both executor-only and co-designer teachers. It should be noted that junior pupils in the executor-only case were younger than the junior pupils in the re-designer case. The age difference may explain the large effect size for the difference in learning outcomes between the experimental and control for junior pupils in the executor-only case. Another limitation is the absence of senior pupils in re-designer case and the absence of junior pupils in codesigner case. Ideally both senior and junior pupils should be involved in all three cases to allow for separate learning outcome comparisons. However, because this study was performed under natural conditions in the kindergarten classrooms of volunteer teachers, the cost of being able to control all variables was accepted in exchange for the benefit of high ecological validity. A further limitation concerns the co-designer case control group, which consisted of pupils from a different school than the pupils in the experimental group. Although, teachers from the different schools were similar with regard to their perspectives about teaching/learning, early literacy and technology, it remains possible that differences in teaching early literacy may have influenced pupil learning outcomes. In this study, the pupil assignment to experimental and control group from a same school was not possible because there were no other kindergartens at that school.

\subsection{Discussion}

This study explored three different teacher roles to provide insight into the value of the roles in designing and implementing technology-rich activities for early literacy.

Across all three teacher roles, significant pupil learning outcomes were found between experimental and control groups. In each role, the effect of PictoPal on pupil learning outcomes was large. Yet, between roles significant differences were found in integration, with highest integration in the co-designer role, medium in the re-designer role, and lowest in the executor role. However, a link between pupil learning outcomes and implementation findings cannot be made easily. Findings showed that, compared to their respective pupil control groups, statistically significant levels of learning took place in cases with low, medium and high levels of implementation. This finding is consistent with those from other studies. Lowther et al., (2012) found no significant effects on pupils' achievement, when teachers were involved in a technology integration program, while other studies (Block et al., 2007; Savage, Erten, Abrami, Hipps, Comaskey, \& Lierop, 2010) show a positive relationship between teacher involvement in technology use programs and pupil learning outcomes. 
Differences in teacher perspectives about their assigned roles might be explained by the differences in years of teaching experience. Re-designer teachers had relatively few years of teaching experience as compared to executor-only and co-designer teachers. While some studies show that in experienced teachers' classrooms students use more and a wider variety of technologies as in the beginning teachers' classrooms (Wetzel, Zambo, \& Ryan, 2007), others show that novice teachers are more likely to use technology in their classrooms than experienced teachers. A study by Mueller, Wood, Willoughby, Ross, and Specht (2008) showed that years of teaching experience do not significantly affect technology integration, while a study by Inan and Lowter (2010) showed that teachers readiness to integrate technology decreases when teachers' years of experience increase, indicating that veteran teachers' readiness and technology integration were lower in comparison to less-experienced teachers. It is plausible that in contrast to experienced teachers, less experienced teachers have more experience with technology and computer proficiency (Inan \& Lowther, 2010) and are less hesitant to use it, but lack practical strategies to overcome barriers to technology integration such as beliefs about teacher-student roles (Ertmer, 2005) or resources to overcome barriers to technology integration (Mueller et al., 2008).

A possible explanation for why higher teachers' integration was not related to higher pupils' learning outcomes could be sought in autonomy of pupils during the off computer activities. Since the teachers in the executor role had the lowest extent of integration, it is plausible that they provided less instruction to children and that they initiated less and offered more space for children to work and learn autonomously, without much interference of teachers. From the effect sizes for the proportion of variance in learning outcomes explained by learning with PictoPal in the executor-only role, it can be cautiously stated the children in the executor role may have learned slightly more than children in the cases of re-and codesigner roles. Another explanation for why higher teacher's integration did not acompany higher pupil learning outcomes may be a slightly better quality of the ready-made PictoPalactivities in the executor-only case, compared to the re-and co-designed materials. Expert reviewing of the different materials can account for this variable in future research.

\subsubsection{The executor-only role}

The executor-only teachers welcomed their role, most likely because they were provided with ready-made curriculum activities and materials. However, executor-only views about practicality were primarily concerned with (junior) pupils' independent use of PictoPal. It could be that during implementation, executor-only teachers observed that pupils need teacher guidance and feedback, which was in sharp contrast with their own preferences for pupils to work independently with PictoPal. This could have prompted teachers to think about using PictoPal at a level appropriate to junior (and senior) pupils' abilities. However, as previously shown (e.g. Klein, Nir-Gal, \& Darom, 2000), teacher guidance affects pupils' performance positively, because teachers can create learning experiences at appropriate pupil ability levels. A link between implementation of technology-rich activities and pupil early literacy outcomes was less clear. A study of Savage et al., (2010) identified no significantly greater pupil learning literacy outcomes in the condition in which teachers did not implement an technology-rich program effectively (e.g. no well-planned activities) compared to pupils not exposed to intervention. The executor-only role contributed to PictoPal-effectiveness, as 
indicated by the large effect found for pupil learning gains. However, teachers struggled with the practicality of PictoPal, which could obstruct implementation in the long run.

\subsubsection{The re-designer role}

In contrast to executors, re-designers were not only concerned with (junior) pupils' (independent) use of PictoPal, but also with their role. In the long run, re-designers may not be inclined to provide teacher guidance to all pupils because, similar to executors, redesigners wanted PictoPal to accommodate independent use by pupils. Compared to codesigner implementation, re-designers integrated PictoPal-activities to a significantly lower extent. It is plausible that teachers' involvement in re-design has provided them with an opportunity to understand the purpose of the curriculum materials. This indicates that the involvement may have contributed to the higher extent of integration (as compared to that of the executors). An explanation for why the re-designer extent of integration was lower than that of co-designers could be the rather reserved perspective re-designers had about their role, which they considered not to be part of teachers daily practice. Teacher perspectives about their role can pose barriers for implementing technology in their classes. A possible explanation for lower extent of integration in re-designer case could be a lower sense of coownership, compared to co-designers. The differences between re- and co-designers' perspectives about their role and sense of co-ownership highlight the importance of how teachers are engaged in designing technology-rich learning activities. Implementation findings indicated that the re-designer role contributes to implementation of PictoPal, more than executor-only role.

\subsubsection{The co-designer role}

Involvement in co-design has provided teachers with an opportunity to understand the purpose of PictoPal, which could have contributed to a higher extent of integration in the codesigner case compared to executor-only case. The implementation findings support the finding of Penuel et al., (2007) that co-design stimulates actual curriculum use. When comparing co- designers and re-designers, there was a discrepancy in implementation, with higher integration for co-designers, despite equal teacher involvement (time, and effort) in (co-and re-)design. Also, the perspective on curriculum practicality could be explanatory for implementation. Co-designer teachers, with the highest extent of integration, perceived PictoPal as good for future use, congruent with pupils' needs, and were positive about the ratio of effort invested and the benefits gained. The findings support the previously identified link between perceiving a curriculum useful and a greater chance to implement the curriculum (Wozney et al., 2006). Another explanation, for higher integration for co-designers compared to re-designers, is the finding that co-designers felt co-ownership, while re-designers felt contributors to the design. The findings support the notion that involvement in curriculum development can be fruitful for implementation and can create a sense of ownership (Fullan, 2003).

\subsection{Conclusion}

The conclusion that all teacher roles contribute to the effectiveness as suggested by large effect sizes for the learning gains in each condition associated with different teacher roles should be taken modestly, since the mixed classes did not allow further analyses concerning 
the differences in pupil learning outcomes between with the cases. Future research should examine how teachers in the executor-only, re-designer and co-designer roles affect opportunities for pupil learning when designing and implementing activities, to offer more insight in the relationship between curriculum implementation and pupil learning outcomes. Pupil early literacy development can be stimulated by technology rich-activities implemented by teachers with different roles, but a high extent of integration of technology activities is most likely to occur in kindergarten classes of teachers as co-designers.

From this study, several implications can be derived. First, the implementation of technology-rich activities can be improved through teacher involvement in re-design or codesign. Second, when planning the innovation, teachers should be informed prior to involvement about the possible roles, as well as the responsibilities and (dis-)advantages of each. Comparing and contrasting the various roles with teachers could help them identify the role that suits them best. Teachers raising practicality concerns about technology-rich activities should be supported in designing ways to overcome their concerns, since teacher views about the practicality of technology-rich activities seemed positively related to implementation of the activities. 


\section{References}

Abrami, P.C., Poulsen, C., \& Chambers, B. (2004). Teacher motivation to implement an educational innovation: Factors differentiating users and non-users of cooperative learning. Educational Psychology, 24, 201-216.

Amante, L. (2007). The ICT at Elementary School and Kindergarten: reasons and factors for their integration. Sísifo / Educational Sciences Journal, 3, 49-62.

Assel, M.A., Landry, S.H., Swank, P.R., \& Gunnewig, S. (2007). An evaluation of curriculum, setting, and mentoring of the performance of children enrolled in prekindergarten. Reading and Writing, 20, 463-494.

Block, C.C., Campbell, M.J., Ninon, K, Williams, C. Helgert, M. (2007). Effects of AWARD Reading, a Technology-Based Approach to Literacy Instruction, on the Reading Achievement and Attitudes Toward Reading of Diverse K-1 Students. Charlotte, NC: The Institute of Literacy Enhancement, Research Report 124811.

Bølgan, N. (2012). From IT to Tablet: Current Use and Future Needs in Kindergartens. Nordic Journal of Digital Literacy, 3, 154-170.

Broadhead, P. (2001). Curriculum change in Norway: thematic approaches, active learning and pupil cooperation-form curriculum design to classroom implementation. Scandinavian Journal of Educational Research, 45, 19-36.

Carl, A. (2009). Teacher Empowerment through curriculum development. Theory into practice. Cape Town: Juta.

Cheung, A.C.K., \& Slavin, R.E. (2012). How features of educational technology applications affect students reading outcomes: A meta-analysis. Educational Research Review, 7, $198-215$.

Cohen, J. (1988). Statistical power analysis for the behavior sciences. Hillsdale, NJ: Lawrence Erlbaum Associates.

Cviko, A., McKenney, S., \& Voogt, J. (2012). Teachers enacting a technology-rich curriculum for emergent literacy. Educational Technology Research \& Development, 60, $31-54$.

Cviko, A., McKenney, S., \& Voogt, J. (2013). The teacher as re-designer of technology integrated activities for an early literacy curriculum. Journal of Educational Computing Research, 48, 447-468.

De Grove, F., Bourgonjon, J., \& Van Looy, J. (2012). Digital games in the classroom? A contextual approach to teachers' adoption intention of digital games in formal education. Computers in Human Behavior, 28, 2023-2033.

DeVellis, R.F. (1991). Scale development. Newbury Park, NJ: Sage Publication.

Dickinson, D.K., \& Caswell, L. (2007). Building support for language and early literacy in preschool classrooms through in-service professional development: Effects of the Literacy Environment Enrichment Program (LEEP). Early Childhood Research Quarterly, 22, 243-260.

Doyle, W., \& Ponder, G.A. (1978). The Practicality Ethic in Teacher Decision-Making. Interchange, $8,1-12$. 
Ertmer, P.A. (2005). Teacher Beliefs: The final frontier in our quest for technology integration? Educational Technology Research Development, 53, 25-39.

Fishman, B.J., Marx, R.W., Best S. \& Tal, R.T. (2003). Linking teacher and student learning to improve professional development in systematic reform. Teaching and Teacher Education, 19, 643-658.

Frechtling, J.A., Zhang, X., \& Silverstein, G. (2006). The Voyager Universal Literacy System: Results from a Study of Kindergarten Students in Inner-City Schools. Journal of Education for Students Placed at Risk, 11, 75-95.

Fullan, M. (2003). Change Forces with a Vengeance. New York: RoutledgeFalmer.

Fullan, M. (2011). Choosing the wrong drivers for whole system reform. Centre for Strategic Education Seminar Series Paper, 204, 1-19.

Fullan, M., \& Watson, N. (2000). School-based Management: Reconceptualising to Improve Learning Outcomes. School Effectiveness and School Improvement, 11, 453-473.

Grossman, P. \& Thompson, C. (2004). Curriculum Materials: Scaffolds for New Teacher Learning? Seattle, WA: Center for the Study of Teaching and Policy. University of Washington. Research Report R-04-1.

Handler, B. (2010). Teacher as Curriculum Leader: A Consideration of the Appropriateness of that Role Assignment to Classroom-Based Practitioners. International Journal of Teacher Leadership, 3, 32-42.

Herrington, J., Specht, M., Brickell, G., \& Harper, B. (2009). Supporting Authentic Learning Contexts Beyond Classroom Walls. In R. Koper (Ed.), Learning Network Services for Professional Development (pp. 273-288). Berlin, Germany: Springer Verlag.

Hutinger, P.L., Bell, C., Daytner, G., \& Johanson, J. (2006). Establishing and Maintaining an Early Childhood Emergent Literacy Technology Curriculum. Journal of Special Education Technology, 21, 39-54.

Hyun, E. \& Davis, G. (2005). Kindergartners' Conversations in a Computer-Based Technology Classroom. Communication education, 54, 118-135.

Inan, F.A., \& Lowther, D.L. (2010). Factors affecting technology integration in K-12 classrooms: a path model. Educational Technology Research and Development, 58, 137154.

Keengwe, J., \& Onchwari, G. (2009). Technology and Early Childhood Education: A Technology Integration Professional Development Model for Practicing Teachers. Early childhood Education Journal, 37, 209-218.

Ketelhut, D.J., \& Schifter, C.C. (2011). Teachers and game-based learning: improving understanding of how to increase efficacy of adoption. Computers \& Education, 56, 539546.

Kim, C. Kim, M., Lee, C., Spector, J.M., \& DeMeester, K. (2013). Teacher beliefs and technology integration. Teaching and Teacher Education, 29, 76-85.

Kirk, D., \& MacDonald, D. (2001). Teacher voice and ownership of curriculum change. Journal of Curriculum Studies, 33, 551-567.

Klein, P.S., Nir-Gal, O., \& Darom, E. (2000). The use of computers in kindergarten, with or without adult mediation; effects on children's cognitive performance and behaviour. Computers in Human Behavior, 16, 591-608. 
Landry, S.H., Swank, P.R., Anthony, J.L., \& Assel. M.A. (2011). An experimental study evaluating professional development activities within a state funded pre-kindergarten program. Reading and Writing 24, 971-1010.

Levy, R. (2009). You have to understand words . . .but not read them': young children becoming readers in a digital age. Journal of research in reading, 32, 75-91.

Lowther, D.L., Inan, F.A., Ross S.M., \& Strahl, J.D. (2012). Do one-to one initiatives bridge the way to $21^{\text {st }}$ century knowledge and skills? Journal of Educational Computing Research, 46, 1-30.

McCutchen, D., Abbott, R.D., Green, L.B., Beretvas, S.N., Cox, S., Potter, N.S., Quiroga, T., \& Gray, A.L. (2002). Beginning Literacy: Links Among Teacher Knowledge, Teacher Practice, and Student Learning. Journal of Learning Disabilities, 35, 69-86.

McKenney, S., \& Voogt, J. (2006). Emergent literacy test for 4-5 year olds. Enschede: University of Twente.

McKenney, S., \& Voogt, J. (2009). Designing technology for emergent literacy: The PictoPal initiative. Computers \& Education, 52, 719-729.

McGrail, (2005). Teachers, technology, and change: English teachers' perspectives. Journal of Technology and Teacher Education, 13, 5-24.

Miles, M.B., \& Huberman, A.M. (1994). Qualitative Data Analysis: An Expanded Sourcebook. Thousand Oaks, CA: SAGE.

Mueller, J., Wood, E., Willoughby, T., Ross, C., \& Specht, J. (2008). Identifying discriminating variables between teachers who fully integrate computers and teachers with limited integration. Computers \& Education, 51,1523-1537.

Neuman, S.B., \& Cunningham, L. (2009). The Impact of Professional Development and Coaching on Early Language and Literacy Instructional Practices. American Educational Research Journal, 46, 532-556.

O’Donnell, C.L. (2008). Defining, Conceptualizing, and Measuring Fidelity of Implementation and Its Relationship to Outcomes in K-12 Curriculum Intervention Research. Review of Educational Research, 78, 33-84.

Parette, H., Quesenberry, A., \& Blum, C. (2010). Missing the Boat with Technology Usage in Early Childhood Settings: A $21^{\text {st }}$ Century View of Developmentally Appropriate practice. Early Childhood Education Journal, 42, 950-961.

Penuel, W.R., Roschelle, J., \& Shechtman, N. (2007). Designing formative assessment software with teachers: An analysis of the co-design process. Research and Practice in Technology Enhanced Learning, 2, 51-74.

Perry, N.E., Hutchinson, L., \& Thauberger, C. (2007). Mentoring Student Teachers to Design and Implement Literacy Tasks that Support Self-Regulated Reading and Writing. Reading \& Writing Quarterly: Overcoming Learning Difficulties, 23, 27-50.

Roschelle, J., Penuel, W.R., \& Shechtman, N. (2006). Co-Design of Innovations with Teachers: Definition and Dynamics. In S.A. Barab, K.E. Hay \& D.T. Hickey (Eds.), Proceedings of the $7^{\text {th }}$ International Conference on Learning Sciences: Vol. 2. Making a Difference (pp. 606-612). Mahwah, NJ: Lawrence Erlbaum Associates.

Savage, R.S., Erten, O., Abrami, P., Hipps, G., Comaskey, E., van Lierop, D. (2010). ABRACADABRA in the hands of teachers: The effectiveness of a web-based literacy intervention in grade 1 language arts programs. Computers \& Education, 33, 911-922. 
Shirley, M.L., Irving, K.E., Sanalan, V.A., Pape, S.J., Owens, D.T. (2011). The practicality of implementing connected classroom technology in secondary mathematics and science classrooms. International Journal of Science and Mathematics Education, 9, 459-491.

Squire K., MaKinster J., Barnett, M., Luehmann, A.L., \& Barab S.A. (2003). Designed curriculum and local culture: Acknowledging the primacy of classroom culture. Science Education, 87, 468-489.

Ten Brummelhuis, A., \& Van Amerongen, M. (2010) Vier in Balans Monitor 2010. Ict in het onderwijs: de stand van zaken. [Four in Balance Monitor 2010: Ict at Dutch schools.] Retrieved from: http://issuu.com/kennisnet/docs/four-in-balance-monitor-2010

Tomeson, M.A., van Koeven, E., Schippers, S., \& Klein Tank, M. (2008). TULE - Dutch: contents and activities at the core goals of 2006. Enschede, The Nederlands: SLO.

Tondeur, J., Hermans, R., van Braak, J., \& Valcke, M. (2008). Exploring the link between teachers' educational belief profiles and different types of computer use in the classroom. Computers in Human Behavior, 24, 2541-2553.

Tracey, D.H., \& Young, J.W. (2007). Technology and Early Literacy: The Impact of an Integrated Learning System on High-Risk Kindergartner's Achievement. Reading Psychology, 28,443-467.

Verseput, N. (2008). Picto-Integration test. Enschede: University of Twente.

Verseput, N. (2008). Pictopal in practice: integration of ICT-related activities to support early literacy in classroom practice. Enschede: University of Twente.

Wetzel, K., Zambo, R., \& Ryan, J. (2007). Contrasts in classroom technology use between beginning and experienced teachers. International Journal of Technology in Teaching and Learning, 3, 15-27.

Wozney, L., Venkatesh, V., \& Abrami, P.C. (2006). Implementing Computer Technologies: Teachers' Perceptions and Practices. Journal of Technology and Teacher Education, 14, 173-207.

Yin, R.K. 2003. Case Study Research Design and Methods. Thousand Oaks: Sage. 


\section{Figures}

Fig. 1. Creating text on-computer (left); using text off-computer (right)

Fig. 2. Distribution of implementation data on the twelve integration items per teacher role.

Fig. 3. Distribution of the integration means for each role over eight weeks (for eight activities during eight weeks).

\section{Tables}

\section{Table 1.}

Overview of the participants per case: executor-only, re-designer and co-designer; teaching experience (years); school and class teaching.

\section{Table 2.}

Overview of the participating pupils per case number, gender, mean age (months).

\section{Table 3.}

Cross case analysis of teacher perspectives: executor-only, re-designer and co-designer.

\section{Table 4.}

Integration means and standard deviation per teacher role.

\section{Table 5.}

Number of junior and senior pupils, means and standard deviation of pre and post-test means and standard deviations, and effect size per teacher role and its control group.

\section{Appendix}

Appendix 1 